See discussions, stats, and author profiles for this publication at: https://www.researchgate.net/publication/295073353

\title{
Milan Kundera and the Poetics of Novelistic Truth
}

Article in Poetics Today · September 2015

DOI: $10.1215 / 03335372-3160721$

CITATION

1

1 author:

Daniel Just

Bilkent University

24 PUBLICATIONS 34 CITATIONS

SEE PROFILE
READS

424 


\title{
Milan Kundera and the Poetics of Novelistic Truth
}

\author{
Daniel Just
}

Bilkent University, Political Science

\begin{abstract}
While not all literary fictions teach us valuable truths about life and the world, this expectation is what makes most of us read them. Literary texts communicate their truths in various ways, but what all of them have in common is that their truths are irreducible to unequivocal statements and propositions. The fact that narrative operation often implies a poetics of truth telling makes literary narratives - and complex novels, above all - a privileged genre for conveying insights about life and the world, especially at a time when we no longer believe in one absolute truth universally applicable to everyone. Milan Kundera's The Unbearable Lightness of Being is an exemplary case. Instead of telling us in what to believe and how to act, this novel obliquely offers a more general kind of truth and attitude toward life: it proposes that life is better lived if we dispense with the need to be recognized, accepted, and valued by others. Far from any didacticism, however, the way this truth is communicated underscores the individual process of reaching it in and even beyond the reading.
\end{abstract}

Keywords novel, readerly reflection, transformative fictions, Milan Kundera

[A novel] can either impress us (if, that is, it is one of the very good ones) with the sort of truths that Nietzsche, Kafka and Dostoevsky tell us, or with the truths that Tolstoy and Trollope tell us. To the first kind we respond with amazement and delight, awe even. "Of course that's it! Of course that's it!" The second kind of truths are more sober, more laboriously constructed, more ultimately reassuring. They are the truths necessary for fiction, and therefore necessary for life. The first

I would like to thank Meir Sternberg for his extensive comments.

Poetics Today 36:3 (September 2015) DOI 10.1215/03335372-3160721

(C) 2016 by Porter Institute for Poetics and Semiotics 
kind contribute brilliantly not to life itself but to what seems an understanding of it. And that too is necessary for us, or at least desirable, and enjoyable.

John Bayley, "Kundera and Kitsch," 1984

What do novels teach us? What truths can they tell us at a time when so many of us no longer believe in absolute truths and one image of life that fits all? Friedrich Nietzsche's truths, and to some extent Franz Kafka's and Fyodor Dostoevsky's as well, are indeed communicated more directly than those of Leo Tolstoy and Anthony Trollope, but even they are rarely final and universal. As with Tolstoy and Trollope, Kafka's and Dostoevsky's brilliant observations and eye-opening revelations are rendered less definite and authoritative by the stories in which they appear. What most of us expect from novels are both enlightening statements and more sober and oblique insights. But what is the poetics of truth telling in novels that contain both types of truths? Do these truths remain separate, coexisting side by side, or do they merge and form a new whole? Are these truth-composite novels, as John Bayley (1984: 18) suggests in reference to Milan Kundera's Unbearable Lightness of Being (1984), narratives in which the author is "the purveyor of Nietzschean truth, but the story is of the Tolstoyan kind," or is another mode of novelistic truth telling involved here? Do such novels contribute to life itself, to an understanding of life, or somehow to both?

Focusing on these questions, the following discussion will examine the structure of semiotic oppositions in The Unbearable Lightness of Being, the novel's technique of discontinuity, and its intrusive narrator. The goal of these analyses is to theorize a type of literary narrative that communicates its truths by stimulating the individual practice of reaching them. By shifting (or at least extending) the emphasis from the narrative forward movement to reflection, questioning, and reevaluation, this type of narrative activates readers' personal investments in literary truths. Although triggered by the act of reading, the process of attaining truths contained in such literary texts ultimately transcends it, so that the personal practice of reflection initiated by this act reaches beyond the immediate time of reading.

The perspective on reading literary fictions in this essay adopts the view that most of us read them because they offer valuable truths about life and the world. A variety of critics and theorists, beginning with Aristotle, would disagree, and this essay does not rule out such other positions. But it takes seriously Rita Felski's (2008: 1) argument that something important about literature gets lost when we limit our approach to what she calls "permanent diagnosis": an academic approach of problematizing, interrogating, and subverting literary texts. Although statements in this essay, such as "most readers" or "often when we read," suggest a different approach than perma- 
nent diagnosis, they do not promote an uncritical and anti-intellectual attitude toward reading. Nor does this article argue for a strict opposition between scholarly and lay reading. As John Guillory (2000: 42; 2008: 12) points out, these two types of reading are distinct but not dichotomous, because even literary scholars read for other than professional reasons and engage with books outside their areas of expertise.

\section{A Book of Questions}

Introducing the issue of novelistic truth telling with questions, as I did above, is not arbitrary, since in many respects The Unbearable Lightness of Being is a book of questions. Like most novels, it encourages readers' active engagement with the text by stimulating their faculties of questioning, but it also, through the narrator, directly poses and answers questions. Together with the structural division into unusually short chapters and the brusque narrative style which uses ellipsis and condensation rather than ornament and intricate grammatical structures, questions and philosophical reflections are the most distinctive features of this novel, as some of its analysts have already observed (Chvatík 1989: 34; 1994: 100-101). These questions are posed and answered by the narrator, who, as we will see, does not always tell us everything. His style of questions and answers differs from the ironic use of the question-and-answer form in James Joyce's Ulysses (1986). ${ }^{1}$ In Kundera's novel questions interrupt the narration in favor of discursive passages that discuss in a more abstract fashion the general framework and wider implications of the narrated events. For example:

Was it better to be with Tereza or to remain alone? There is no means of testing which decision is better, because there is no basis for comparison. We live everything as it comes, without warning, like an actor going on cold. And what can life be worth if the first rehearsal for life is life itself? That is why life is always like a sketch. No, sketch is not quite the word, because sketch is an outline of something, the groundwork for a picture, whereas the sketch that is our life is a sketch for nothing, an outline with no picture. (Kundera 1984: 8) ${ }^{2}$

1. An example is the following passage from chapter 17 of Ulysses: "What act did Bloom make on their arrival at their destination? At the housesteps of the $4^{\text {th }}$ of the equidifferent uneven numbers, number 7 Eccles street, he inserted his hand mechanically into the back pocket of his trousers to obtain his latchkey. Was it there? It was in the corresponding pocket of the trousers which he had worn on the day but one preceding. Why was he doubly irritated? Because he had forgotten and because he remembered that he had reminded himself twice not to forget" (Joyce 1986: 546).

2. English translations are modified to follow more closely the idiosyncratic grammar and lexis of the Czech original, Nesnesitelná lehkost bytí (Kundera 1985). 